Journal of Applied Pharmaceutical Science Vol. 5 (06), pp. 097-103, June, 2015

Available online at http://www.japsonline.com

DOI: $10.7324 / \mathrm{JAPS} .2015 .50616$

ISSN 2231-3354 (cc) BY-NC-SA

\title{
Survey on the Pharmaceutical Quality of Herbal Medicines Sold in Nigeria
}

\author{
Philip F. Builders ${ }^{1}$, Chris A. Alalor ${ }^{2}$, John A. Avbunudiogba ${ }^{2}$, Isreal E. Justice ${ }^{2}$ \\ ${ }^{1}$ Department of Pharmaceutical Technology and Raw Materials Development, National Institute for Pharmaceutical Research and Development, Abuja, \\ Nigeria. ${ }^{2}$ Department of Pharmaceutics and Industrial Pharmacy, Faculty of Pharmacy, Delta State University, Delta State, Nigeria.
}

\section{ARTICLE INFO}

Article history:

Received on: 21/12/2014

Revised on: $13 / 02 / 2015$

Accepted on: 17/04/2015

Available online: 27/06/2015

Key words:

Herbal medicine, regulatory

guidelines, pharmaceutical

quality

\begin{abstract}
In recent times the apparent upsurge in the popularity and use of herbal medicines can be related to the success in their use for the management of certain important diseases, empirical proof of efficacy and safety, enhanced dosage form design and better tolerance among others. In this study the quality of some herbal medicines sold in Nigeria were evaluated for basic pharmaceutical quality and compliance to regulatory guidelines. Samples of sixteen frequently used herbal products were collected from Pharmacy stores (Ps) and Patent Medicine stores (PMs) across two states and the Federal Capital Territory. The dosage form, organoleptic properties, moisture content, weight/volume uniformity as well as compliance to regulatory guidelines were evaluated. Sixty percent of the samples were liquids, thirty percent were oral bulk powders and ten percent were capsules. None of the products complied completely with the regulatory requirement stipulated for finished herbal products in Nigeria while only ten percent of the products samples complied with the basic physicochemical properties required for pharmaceutical quality. Consequently, there is a compelling need for the regulatory authorities to ensure stringent quality surveillance and enforcement of guidelines to ensure that herbal medicines are of standard quality.
\end{abstract}

\section{INTRODUCTION}

Herbal medicines include finished labeled products containing herbal materials as the active ingredient, their traditional use and effectiveness have been verified by pharmacological and clinical evaluations, and are generally used either as complimentary or alternative medicine in health care (Parthic et al., 2011; Zhou et al., 2007). Herbal medicine remains an essential component of the primary health care in many rural African and Asian communities and also an important component of complementary and alternative medicine all over the world (Okigbo and Mmeka, 2006; Barbosa et al., 2012). The World Health Organization (WHO) estimates that as much as $80 \%$ of the populations of some Asian and African countries presently use herbal medicines for some aspect of their primary health care (Zhou et al., 2007). In many parts of the world where herbal medicines are widely used certain factors have militated

\footnotetext{
* Corresponding Author

Philip F Builders, Department of Pharmaceutical Technology and Raw Materials Development, National Institute for Pharmaceutical Research and Development, Abuja, Nigeria.Email: philsonsky@yahoo.com
}

against its inclusion into the main stream health care system. Among the major drawbacks include poor dosage form design and standardization of the products (Okigbo and Mmeka, 2006; Calixto, 2000). In recent times there has been an upsurge in the use of herbal medicines, which has become more mainstream due largely to improvement in regulation, analytical and quality control tools as well as advances in clinical research showing great value in general healthcare and management of certain diseases in which the conventional medicines has not done too well (Chauhan et al., 2013). Though, herbal medicines are frequently considered to be safer than conventional medicines because of their better tolerance. However, there are also reports of side effects and adverse reactions that have been related to herbal medicines (Shiel, 2014; Abebe, 2002). While some of these side effects and adverse drug reactions are due to the intrinsic bioactive secondary metabolites present in the herbal materials, many are due to the poor qualities of the products which may be attributed to such factors as contamination (with chemicals, pesticides, micro organisms and heavy metals), adulteration with pure drug compounds and poor quality control measures. An acceptable herbal product must be safe, stable and presented in a suitable dosage form and package (Firenzuoli et al., 2005). 
In many countries herbal medicines are sold or distributed as nutraceuticals (Chauhan et al., 2013). Nutraceuticals include natural products that provide health benefits, including the prevention and treatment of diseases (Shiel, 2014; Abebe, 2002; Firenzuoli et al., 2005; Trottier et al., 2010). Though, they are not required to follow the rigorous development criteria and regulations of pharmaceutical drugs they are nevertheless required to meet certain quality and regulatory standards to ensure safety, uniformity and acceptability (Wickramasinghe, 2006).

In many countries of the world including Nigeria guidelines are prescribed for imported and locally manufactured herbal products (WHO, 2003; NAFDAC 2013). Nevertheless, herbal medicine is yet to be incorporated into the essential health care system in Nigeria but a high population of those living in rural communities depend essentially on them for their health care (Springfield et al., 2000). The objective of this study is to evaluate the pharmaceutical quality and the compliance to regulatory guidelines of some finished herbal medicines sold in Nigeria.

\section{MATERIALS AND METHODS}

\section{Materials}

Samples of finished herbal medicines (Table 1) were purchased from Ps and PMs across three states in Nigeria (Anambra state, Delta state and Federal Capital Territory, Abuja) without prescription. No pattern was designed for the collection of samples as the products were purchased over the counter from the drug stores wherever they could be found. All other reagents used were of analytical grade and used as supplied.

\section{Methods}

\section{Evaluation of packaging elegance}

The samples of the herbal medicines were coded H1H16 for easy identification. The package elegance was evaluated objectively by a panel of six assesors. The objects assessed were the carton and print quality of the packages. The terms of score were: good, fair and poor.

\section{Label information compliance}

The products were evaluated for label information compliance as prescribed by National Agency for Food and Drugs Administration and Control (NAFDAC), which is the regulatory agency for foods and drugs in Nigeria (NAFDAC, 2015).

The label information requirement evaluated were: brand name, storage condition, manufacturer's name, address and country of manufacture, batch number, manufacture and expiry dates, net content, NAFDAC registration/listing number, symptoms of overdose and antidote notices, contra-indications/ drug interactions, warnings/precautions and disclaimer notice. The percentage level of compliance by the population samples collected was evaluated (NAFDAC, 2013).
Organoleptic properties Herbal capsules

Organoleptic assessments of the herbal capsules were evaluated by a panel of six assessors for odour and general appearance.

\section{Oral bulk herbal powders}

Organoleptic assessment was carried out on all the herbal oral bulk powders. The samples were evaluated objectively for colour, taste, odour and texture by a panel of six assessors, the consensus decision of at least four assessors were considered valid for the test.

\section{Herbal liquid products}

The colour, taste, odour and general appearance of the products were also objectively evaluated by the panel of assessors and the decision of at least four assessors was considered as valid for the test (Mbah et al., 2012).

\section{Weight and volume uniformity Herbal capsules}

Twenty capsules were each weighed. The content of each was removed as completely as possible. The weight of each empty capsule shell was determined. The weight of the contents is the difference between the weight of the intact capsule and the shell. The average weight was then determined. The limit for consideration for this test according to the United States Pharmacopeia is: not more than two of the individual weights should deviate from the average weight by more than $\pm 7.5 \%$ for the capsules equal to $300 \mathrm{mg}$ (United States Pharmacopeia, 2007).

\section{Oral bulk herbal powders}

Twenty sachets of each brand of herbal powder products were picked at random and emptied completely into a $100 \mathrm{ml}$ beaker and the weight of each sachet was determined. Not more than 2 of the individual weights should deviate from the average weight by more than $\pm 7.5 \%$ and none should deviate by more than 14\% (United States Pharmacopeia, 2007).

\section{Oral liquid}

The volume uniformity of the herbal liquid products was evaluated by selecting six samples of each product at random. The content of each bottle was emptied into a $250 \mathrm{ml}$ measuring cylinder and the volume determined.

\section{Flow properties}

Quantities of the herbal capsules and oral bulk herbal powders were emptied into a $500 \mathrm{ml}$ measuring cylinder to obtain at least $50 \mathrm{~g}$ of powder. The volume $\left(\mathrm{V}_{\mathrm{B}}\right)$ occupied by $50 \mathrm{~g}$ of each powder was determined using a $200 \mathrm{ml}$ graduated measuring cylinder. The tapped volume $\left(\mathrm{V}_{\mathrm{T}}\right)$ which corresponds to the volume of final powder consolidation after tapping with an automated tapping machine (Stampfvolumeter, STAV 2003JEF, 
Germany) was determined for each brand of sample. The bulk and tapped densities were evaluated and used to determine the powder compressibility index (CI) using the formula represented by equation 1.

$$
\mathrm{CI}=\left[\left(\mathrm{V}_{\mathrm{B}}-\mathrm{V}_{\mathrm{T}}\right) / \mathrm{V}_{\mathrm{B}}\right] \times 100 \ldots . .1
$$

The angle of repose of the powders was determined for each sample by measuring the internal angle between the surface of the heap of the powder obtained when $50 \mathrm{~g}$ of each of the powder sample was allowed to flow through a glass funnel (orifice diameter $1 \mathrm{~cm}$ ) and clamped $10 \mathrm{~cm}$ above a flat surface. The angle of repose was determined using equation 2 (Well, 2003).

Angle of repose $=$ Tan $\Theta=$ Height of cone $\quad \ldots .2$

Radius of cone (r)

\section{Moisture content}

The moisture content of $1 \mathrm{~g}$ of each sample product of the oral bulk powder and herbal capsules were determined using a moisture balance (Gronert 4937-Ultra X, Germany).

\section{Disintegration time of herbal capsules}

Six capsules of each herbal capsule product were placed in the sample holder of the disintegration machine (Erweka ZT4, Germany) and subjected to the disintegration process. The disintegration medium was water maintained at temperature of $37 \pm 2{ }^{\circ} \mathrm{C}$. The run was stopped when only the residue remaining in the screen consists of only palpable fragments of the capsule shell (British Pharmacopeia, 1993).

\section{RESULTS}

The extent of the compliance of the herbal products to the regulatory requirements and guidelines as stipulated by NAFDAC for packaging and labeling are presented in Fig. 1. Only about $40 \%$ of the product showed good package presentation as regards the package carton quality and print graphic and color quality. All the products showed compliance as regards inclusion of brand names, batch number, NAFDAC registration number, manufacture date, expiry date and net content. None of the products included any information on contra-indications, interactions (with food and other medicines), warnings/ precautions, disclaimer notice, symptoms of overdose and antidote for overdose or toxicity.

\section{Organoleptic Properties}

The taste, odour, colour, texture and general appearance of the herbal capsules, powders and liquid products are presented in Tables 2. The herbal capsule products were generally elegant and all were packed in size 0 hard gelatin capsules. When the content of the capsules were examined, all the products were fine powders with a smooth fine texture. Their colours were either brown or pale green and all tasted bitter with a characteristic herbal odour. The herbal oral bulk powder products were either brown or black as presented in Table 1. Only one of the products had a smooth texture the others were coarse irregular shaped particles. Each of the two oral bulk powder products had a weak near odourless and a characteristic leafy odour respectively, while the others had odours that were characteristic and pungent. The tastes of the liquid products were predominantly bitter and their colours were different shades of brown. Their odours ranged from characteristic leafy, pungent to odourless. The feel to touch of the liquid herbal products was either moderately gritty (apparently containing minute particles) or smooth. The general appearance of the package, label carton and print quality of over sixty percent of the products (Fig. 1) as objectively assessed by the panel of assesors was non-elegant. Over $85 \%$ of the liquid products contained sediments and are without the caution "shake the bottle".

\section{Moisture content}

The results of the moisture content of the powders are presented in Tables 3 and 4 . The moisture content of the products showed remarkable variation among the different products. Neither the capsule nor the bulk oral powders showed any relative pattern in the moisture content.

\section{Weight and volume uniformity}

The weight uniformity of the herbal capsules and oral bulk powder products are presented in Table 3 and 4 respectively. The standard deviations of the measured weights of the herbal capsules were high corroborating the large differences in the weights of individual capsules of each product. When evaluated with the USP test for uniformity of weights none of the samples complied with the criteria for acceptance (United States Pharmacopoeia, 2007). For the three products more than two samples of the twenty randomly selected samples of each deviated from the average by more than $\pm 7.5 \%$ also at least two of each capsule product samples deviated by more than the stipulated $15 \%$ of the average weight. None of the herbal capsule products complied with the limit test for weight uniformity indicated for capsules of average weights of 120 to $324 \mathrm{mg}$ as prescribed by USP/NF (United States Pharmacopoeia, 2007). The weight and the volume uniformity in relation to the labeled claims of the oral bulk powder are presented in Table 4. Only one of the products of the oral bulk powders complied with the criteria for acceptance for weight uniformity. All the oral bulk powder products were over twice the weights on the label. One of the oral bulk powder products was mislabeled; the content was presented in volumetric unit instead of gravimetric. It also did not conform to weight uniformity as prescribed by the USP (United States Pharmacopoeia, 2007). However, all except one of the oral liquid products showed acceptable volume uniformity (Table 4).

\section{Micromeritic properties}

The bulk and tapped densities, Carr's index and angle of repose of the powder content of the herbal capsules and bulk oral herbal powders are presented in Table 5. The powders have variable bulk and tapped densities as well as the flow properties as predicted by the angle of repose and Carr's compressibility index. 
Table 1: Particulars of herbal medicines samples evaluated.

\begin{tabular}{|c|c|c|c|c|c|c|}
\hline $\begin{array}{l}\text { Code } \\
\text { name }\end{array}$ & Brand name & Batch No & $\begin{array}{l}\text { NAFDAC } \\
\text { No }\end{array}$ & $\begin{array}{l}\text { Manufactured } \\
\text { date }\end{array}$ & Expiry date & Manufacturer \\
\hline H1 & SUPA A1 natural capsule(380mg) & 150713 & A7-0374L & July/2013 & July/2016 & YEM-KEM Intl \\
\hline $\mathrm{H} 2$ & BAFAJ A-plus herbal remedy & 010 & A7-0829L & $01 / 06 / 2013$ & $02 / 06 / 2015$ & $\begin{array}{l}\text { Herbsense and gen. merchant } \\
\text { Nig. Ltd }\end{array}$ \\
\hline H3 & M \& T capsule & 150723 & A7-0294L & June/2013 & June/2016 & YEM-KEM Intl \\
\hline $\mathrm{H} 4$ & Redeemer's zion blended herbal mixture $(5 \mathrm{~g}) 13$ & 006 & A7-0280L & $02 / 07 / 2012$ & 02/07/2014 & EAC Global trado Ltd \\
\hline H5 & Thuja 1000 powder $(4 \mathrm{~g}) 10$ & 02 & $04-6222 \mathrm{~L}$ & $20 / 03 / 2013$ & 20/03/2015 & C.J Onuora \& sons Ltd \\
\hline H6 & Jalin powder(5g) 17 & 010 & A7-6734L & $05 / 09 / 2013$ & 05/09/2016 & EAC Global trado Ltd \\
\hline H7 & Omega roots + ginseng $(300 \mathrm{ml}) 17$ & 04 & $04-8618 \mathrm{~L}$ & $02 / 02 / 2012$ & $02 / 02 / 2015$ & EAC Global trado Ltd \\
\hline $\mathrm{H} 8$ & Swidish bitters & A-044 & A7-0126L & $02 / 02 / 2012$ & $02 / 02 / 2015$ & - \\
\hline H9 & African Iba Mixture & B-008 & A7-0476L & $12 / 2013$ & $12 / 2016$ & GN ALAGOSO \& SONS LTD \\
\hline H10 & $\begin{array}{l}\text { Dr. IGUEDO's GOKO CLEANSER Herbal } \\
\text { Mixture }\end{array}$ & 0005 & A7-0804L & $3 / 2013$ & $02 / 2017$ & $\begin{array}{l}\text { GOKO HERBS WEST } \\
\text { AFRICA LTD }\end{array}$ \\
\hline H11 & Yoyo bitters & B-008 & A7-055L & $10 / 2013$ & $10 / 2015$ & $\begin{array}{l}\text { ABLLAT COMPANY NIG } \\
\text { LTD }\end{array}$ \\
\hline H12 & Dr.Nando 77 Keys To Power Herbal Mixture & & A7-0804L & $07 / 2013$ & $08 / 2015$ & Nando Herbs Nig LTD \\
\hline H13 & Jedi-jedi Mixture & 08 & A7-0415L & $7 / 07 / 2013$ & $7 / 07 / 2016$ & $\begin{array}{l}\text { Ozoms LTD. Ogbogonogo } \\
\text { Asaba Delta State }\end{array}$ \\
\hline H14 & Deep root herbal mixture(500ml) & 008 & A7-0912L & $02 / 02 / 2013$ & $01 / 02 / 2015$ & $\begin{array}{l}\text { FESCO herbal mixture Nig. } \\
\text { Ltd }\end{array}$ \\
\hline H15 & Milenium roots-mixture $(600 \mathrm{ml})$ & 04 & $04-8612 \mathrm{~L}$ & $30 / 03 / 2012$ & $30 / 03 / 2016$ & Johnny-John Pharm. Ltd \\
\hline H16 & Omega roots + ginseng $(600 \mathrm{ml})$ & 03 & $04-8618 \mathrm{~L}$ & $15 / 01 / 2012$ & $15 / 01 / 2016$ & EAC Global trado Ltd \\
\hline
\end{tabular}

Table. 2: Organoleptic properties of the herbal products.

\begin{tabular}{|c|c|c|c|c|c|c|}
\hline $\begin{array}{l}\text { Product } \\
\text { code }\end{array}$ & Appearance & Odour & Texture & Colour & Taste & Dosage form \\
\hline H1 & Elegant & Characteristic herbal & Smooth & Brown & Elegant & Capsule \\
\hline $\mathrm{H} 2$ & Elegant & Characteristic herbal & Smooth & Brown & Elegant & Capsule \\
\hline H3 & Elegant & Characteristic leafy & smooth & Pale green & Elegant & Capsule \\
\hline $\mathrm{H} 4$ & None-elegant & Odourless & Moderately coarse & Brown & None-elegant & Capsule \\
\hline H5 & Elegant & Characteristic herbal smell & Smooth & Black & Elegant & Powder \\
\hline H6 & None-elegant & Rancid & Moderately coarse & Black & None-elegant & Powder \\
\hline $\mathrm{H} 7$ & None-elegant & Rancid & Moderately & Brown & None-elegant & Powder \\
\hline $\mathrm{H} 8$ & Elegant & Alcohol & Smooth & Brown & Elegant & Powder \\
\hline $\mathrm{H} 9$ & Elegant & Characteristic herbal smell & Smooth & Brown & Elegant & Liquid \\
\hline H10 & Elegant & pungent & Clear liquid & Black & Elegant & Liquid \\
\hline H11 & Elegant & characteristic & Clear liquid & Black & Elegant & Elegant \\
\hline H11 & Elegant & characteristic & Clear liquid & Black & Elegant & Elegant \\
\hline H12 & Elegant & characteristic & Clear liquid & Brown & Elegant & Non Elegant \\
\hline H13 & nonElegant & characteristic & Clear liquid & Brown & nonElegant & Elegant [good package] \\
\hline $\mathrm{H} 14$ & $\begin{array}{l}\text { Elegant [good } \\
\text { package] }\end{array}$ & Aromatic & Clear liquid & Brown & Elegant [good package] & $\begin{array}{l}\text { Non Elegant [poor } \\
\text { package] }\end{array}$ \\
\hline H15 & $\begin{array}{l}\text { Non Elegant } \\
\text { [poor package] }\end{array}$ & Characteristic pungent & Clear liquid & Black & Non Elegant [poor package] & $\begin{array}{l}\text { Non Elegant [poor } \\
\text { package] }\end{array}$ \\
\hline H16 & $\begin{array}{l}\text { Non Elegant } \\
\text { [poor package] }\end{array}$ & Characteristic pungent & Clear liquid & Pale green & Non Elegant [poor package] & \\
\hline
\end{tabular}

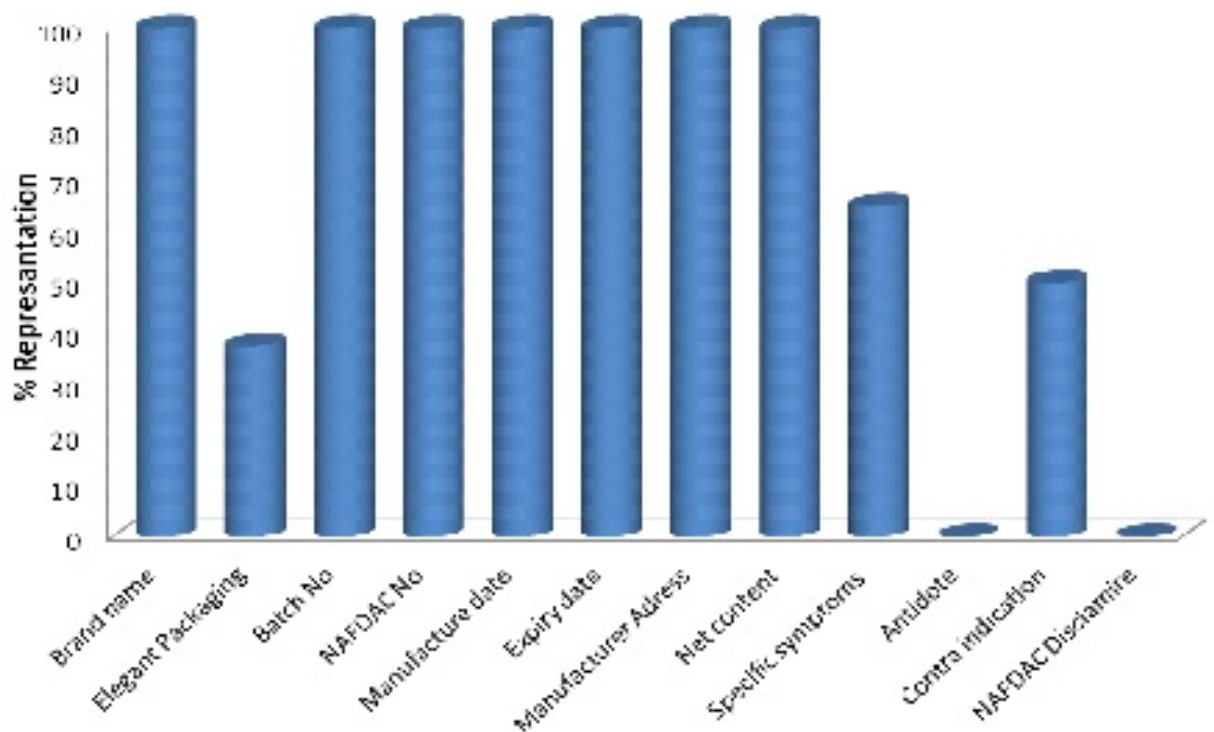

Fig. 1: Label Properties of representative sample of herbal medicines sold in nigeria. 
Table 3: Weight uniformity of the herbal capsules

\begin{tabular}{|c|c|c|c|}
\hline Product code & Average weight (g) & Moisture content (\%) & Disintigration time (min) \\
\hline H1 & $300 \pm 58$ & $10 \pm 1.6$ & $6 \pm 1.0$ \\
\hline H2 & $468 \pm 275$ & $18 \pm 1.1$ & $7 \pm 1.4$ \\
\hline H3 & $296 \pm 62 \mathrm{~g}$ & $13 \pm 1.5$ & $10 \pm 1.7$ \\
\hline
\end{tabular}

Table 4: Weight uniformity of the herbal powders

\begin{tabular}{cccc} 
Product code & Average weight & Claimed quantities & Moisture content \\
H4 & $13.09 \pm 4 \mathrm{~g}$ & $5 \mathrm{~g}$ & $13.09 \pm 4.0 \%$ \\
H5 & $3.85 \pm 0 \mathrm{~g}$ & $4 \mathrm{~g}$ & $10.00 \pm 0.5 \%$ \\
H6 & $12.37 \pm 4 \mathrm{~g}$ & $5 \mathrm{~g}$ & $17.50 \pm 1.5 \%$ \\
H7 & $13.09 \pm 4 \mathrm{~g}$ & $300 \mathrm{ml}$ & $17.10 \pm 2.3 \%$ \\
\hline
\end{tabular}

Table 5: Volume uniformity of the herbal liquids

\begin{tabular}{|c|c|c|}
\hline Product code & Average volume & Claimed quantities \\
\hline H8 & $100 \pm 0 \mathrm{ml}$ & $100 \mathrm{ml}$ \\
\hline H9 & $310 \pm 10 \mathrm{ml}$ & $300 \mathrm{ml}$ \\
\hline H10 & $210 \pm 6 \mathrm{ml}$ & $200 \mathrm{ml}$ \\
\hline H11 & $200 \pm 5 \mathrm{ml}$ & $200 \mathrm{ml}$ \\
\hline H12 & $240 \pm 10 \mathrm{ml}$ & $200 \mathrm{ml}$ \\
\hline H13 & $110 \pm 15 \mathrm{ml}$ & $100 \mathrm{ml}$ \\
\hline H14 & $550 \pm 30 \mathrm{ml}$ & $500 \mathrm{ml}$ \\
\hline H15 & $625 \pm 15 \mathrm{ml}$ & $600 \mathrm{ml}$ \\
\hline H16 & $620 \pm 10 \mathrm{ml}$ & $600 \mathrm{ml}$ \\
\hline
\end{tabular}

Table 6: Some micromeritic properties of the herbal powders

\begin{tabular}{|c|c|c|c|c|}
\hline Parameters & H4 & H5 & H6 & H7 \\
\hline Bulk density $\left(\mathrm{g} / \mathrm{cm}^{3}\right)$ & $0.42 \pm 0.01$ & $0.39 \pm 0.08$ & $0.33 \pm 0.01$ & $0.25 \pm 0.02$ \\
\hline Tapped density $\left(\mathrm{g} / \mathrm{cm}^{3}\right)$ & $0.57 \pm 0.02$ & $0.48 \pm 0.00$ & $0.51 \pm 0.03$ & $0.38 \pm 0.03$ \\
\hline Angle of repose $\left({ }^{\circ}\right)$ & $54 \pm 2.35$ & $51.33 \pm 3.56$ & $52.5 \pm 3.19$ & $54.33 \pm 3.20$ \\
\hline Carr's index $\left({ }^{\circ}\right)$ & $27.05 \pm 3.8$ & $19.96 \pm 3.89$ & $35.17 \pm 4.62$ & $33.39 \pm 1.69$ \\
\hline Flow rate (g/sec) & $0.21 \pm 0.03$ & $0.2 \pm 0.03$ & $0.15 \pm 0.03$ & $0.16 \pm 0.01$ \\
\hline Moisture content & $17 \pm 1.3$ & $13 \pm 1.0$ & $10 \pm 0.8$ & $17 \pm 1.3$ \\
\hline
\end{tabular}

\section{Disintigration time}

The disintegration time of the herbal capsules are presented in Table 3. All the capsules disintegrated within 15 minutes.

\section{DISCUSSION}

The way a product is packaged is the first indicator of product quality. Good packaging creates a sense of value and provides an impression that instills confidence in consumers (Yacuzzi, 2004; Holbrook and Corfman, 1985). That only $40 \%$ of the products showed good package elegance is an evidence of the relative poor packaging habit and low esthetic quality of the herbal products that are sold in Nigeria. Though, the use of natural products especially herbal medicines is becoming increasingly popular in Nigeria but most of those with high acceptance and patronage are the imported products which also have innovative dosage designs and excellent package. The poor packaging could be among the major factors why the locally produced herbal medicines are not popular in Nigeria notwithstanding the availability of wide diversity of useful and portent herbs (Ajibesin et al., 2012; Odugbemi, 2006; Olowokudejo et al., 2008).

The compliance of herbal products to the approved regulatory requirements constitutes a fundamental component of the product quality. The inclusion of the products brand names, batch number, registration number, manufacture date, expiry date and net content in the label information shows the ethical quality and genuineness of the products. This also indicates that all the products can be identified and tracked on a batch to batch level to the producers. There is also an implication that the products has met the appropriate requirement stipulated by the regulatory agency regarding the quality, especially as it relates to product stability and shelf life (Mbah et al., 2012; NSFS, 2006).

The none compliance of all the products to the information on the contra-indications, warnings/precautions on possible drug interactions, symptoms of overdose and antidote for overdose or toxicity may indicate the level of the information on the pharmacology and clinical studies available on the products. The enforcement of the inclusion of these notices will assure safety due to the availability of adequate information required to manage any side effects or adverse reactions that may arise when the products are used.

Organoleptic evaluation is a veritable quality assessment technique that employs sensory testing and comprises of such parameters as taste, smell, colour, general appearance and texture of a product (Kamboj, 2012). It is a simple and versatile technique that has been used to identify and monitor the quality of herbal materials and finished herbal products without the use of analytical aids or machines. Organoleptic evaluation remains the only tool available to many Traditional Medical Practitioners (TMPs) and users of herbal medicines (Saohin et al., 2007). This simple but important technique is the first line test in the quality assessment and acceptance of food and herbs. For known products deviations from known intrinsic characteristic odour, colour, texture and taste often corresponds to such defects as deterioration, adulteration or mix-ups etc. Generally all the herbal products evaluated showed 
variable oganorleptic properties, some of which may be due to the intrinsic properties of the herbal materials and excipients or may be imparted on the products by degradation and deterioration. For a product sold as a food or medicine the aesthetic appearance needs to be generally acceptable. The colour, taste and smell of the product must be especially acceptable to a large population of users. Over $90 \%$ of the products showed general poor organoleptic quality as most of them had very bitter taste and pungent or herbal odour. This shows that probably during the dosage form development little or no consideration was given to product esthetics and user acceptance factors. The unpalatable bitter tastes of the liquid and oral powder products may adversely affect acceptance by many users especially children.

High moisture content corresponds often to high amount of free water which results in high water activity that may alter various physicochemical properties of especially products that are intended to be used or stored dry, it also support the growth of harmful bacteria, yeasts and molds (Saohin et al., 2006; Esimone et al., 2002). The impact of moisture content on the stability and safety of herbal products is significant that is why the European Agency for the Evaluation of Medicinal Products suggested that the water content should be included in the list of comprehensive specifications for herbal materials and finished herbal products that are solids. The variable moisture content of the different products may be due to the intrinsic moisture holding capacities of the herbal materials and the efficiency of the packaging material to protect the products from picking up moisture from the atmosphere (Kamboj, 2012). High moisture content in herbal materials will increase the danger of degradation and deterioration due to enzyme activity and microbial proliferation. This may also affect certain critical formulation properties of the finished product such as the disintegration, release of the bioactive agent and flow of the powdered or granulated products. Other serious secondary defects that can be caused by increased moisture content include unacceptable weight and content variations (Saohin et al., 2007; Esimone et al., 2002). Thus; high moisture content will malign the quality and safety of herbal materials and finished products. To control moisture in herbal products, the USP prescribes storage under relative humidity of below 60\% RH (United States Pharmacopoeia, 2007). Also a maximum moisture content limit of $8 \% / \mathrm{g}$ has been prescribed as been satisfactory for herbal products by NAFDAC (NAFDAC SOP, 2000). The high moisture content of all the oral herbal powders and capsules may mean potential microbial and chemical instability for the products that may create a serious secondary safety problem. The handling of herbal materials and finished products should be controlled to ensure optimal moisture at prepackaging and also prevent moisture pickup during the shelf life.

The evaluations of the micromeritic properties of the herbal powders are important because properties such as appearance, flow and packing are dependent on it (Baba-Moussa, 2013). The variability in the bulk and tapped densities, Carr's compressibility, angle of repose of the oral bulk powders is due to the differences in the particle properties of the powders. The high values of the bulk and tapped densities of the powders apart from those of $\mathrm{H} 7$ can be related to the fluffy nature of the powders (Table 7). This explains the reason for the poor flow of the powdered product as shown by the Carr's compressibility index, angle of repose and flow rates which corresponds to a poor flow characteristics (Well, 2003).

Rapid disintegration which corresponds to a quick breakup of tablets and capsules is one of the critical properties of rapid release solid dosage forms (Nattapulwat, 2008). The rapid breakup of the capsules will influence the quick release and absorption of the bioactive entities contained therein. All the capsules disintegrated in less than 15 minutes which is under the limit time of 15 minutes prescribed by the BP for rapid release capsules (British Pharmacopoeia, 1993). The rapid disintegration may be related to various factors, such as the capsule packing, efficiency of the disintigrant, moisture content that may enhance wetting of the capsule as well as the intrinsic properties of the herbal materials that may enhance disintegration.

\section{CONCLUSION}

To promote the acceptance of locally manufactured herbal medicines the products must show good quality by endearing confidence in both efficacy and physicochemical properties. Basic quality parameter such as organoleptic properties, moisture content, flow and disintegration time are veritable parameters that could be used to evaluate the potential quality of the products. The herbal capsules showed good organoleptic and disintegration properties. However, the oral bulk powders and liquid products did not show adequate elegance in terms of colour, odour and taste. For all the herbal products evaluated the uniformity of content as shown by the weight and volume variation tests, showed that over $70 \%$ the products failed to comply with the official requirement for dose content uniformity. The moisture content of all the powdered products was high enough to potentially compromise stability. Thus, adequate measures should be taken by the regulatory agency to ensure that TMPs and manufacturers of herbal medicines in Nigeria implement adequately, all the components of regulatory guidelines and current good manufacturing practices while also ensuring that the production and quality control processes are appropriately validated.

\section{REFERENCE}

Parthic P, Patel NM, Patel PM. WHO standards on quality control of herbal medicines. IJRAP. 2011; 2(4): 1148-54.

Zhou S, Zhou Z, Li C, Chen X, Yu X, Xue CC, Herington A. Identification of drugs that interact with herbs in drug development. Drug Disco Today, 2007; 12(15-16): 664-73.

Okigbo RN, Mmeka EC. An appraisal of phytomedicine in Africa. KMITL Sci. Tech. J. 2006; 6(2): 83-94.

Barbosa WLR, Nascimento MS, Pinto LN, Maia FLC, Sousa AJA, Silva JOC, Monteiro MM, Oliveira DR. 2012. Selecting medicinal plants for development of phytomedicine and use in primary health care. In: Rasooli I. (Ed) Bioactive Compounds in Phytomedicine. p. 3-24. www.intechopen.com 
Calixto JB. Efficacy, safety, quality control, marketing and regulatory guidelines for herbal medicines (Phytotherapeutic agents). Brazilian J Med Bio Res. 2000; 33(2): 179-189.

Chauhan B, Kumar G, Kalam N, Ansari SH. Current concepts and prospects of herbal nutraceutical: A review. J Adv Pharm Technol Res. 2013; 4(1): 4-8. doi: 10.4103/2231-4040.107494.

Shiel WC. Herbs toxicities and drug interactions. 2014. Medicine net.com Stöppler MC. (Ed).. Source: http://www.medicinenet.com/script/main/art.asp?articlekey=7506.

(Accessed 15 August 2014).

Abebe W. Herbal medication: potential for adverse interactions with analgesic drugs. J. Clinic Pharm Therapeut. 2002; 27(6): 391-401. DOI: $10.1046 /$ j.1365-2710.2002.00444.x

Firenzuoli F, Gori L, Galapai C. Adverse reaction to an adrenergic herbal extracts (Citrus aurantium). Phytomed. 2005; 12(3): 247-248.

Trottier G, Boström PJ, Lawrentschuk N, Fleshner NE. Nutraceuticals and prostate cancer prevention: A current review. Nat Rev Urol. 2010; 7: 21-30.

Wickramasinghe MB. 2006. Quality control, screening, toxicity, and regulation of herbal drugs In: Ahmad I, Aqil F, Owais M. (Ed.). Modern phytomedicine. Turning medicinal plants into drugs. Chapter 2 WILEY-VCH Verlag-Weinheim: p. 25-57.

World Health Organization. 2003. Guidelines for the regulation of herbal medicines in the South-East Asia Region. SEA-Trad. Med.-82 Distribution:

General. http://pharmacy.utah.edu/ICBG/pdf/WebResources/TraditionalMedicines/ WHO-TradMed-Safe-and-Effective.pdf (Accessed 15 August 2014).

NAFDAC: Simple rule on product packaging and labeling in Nigeria: http://www.nlipw.com/wp- content/uploads/2013/07/HERBALMEDICINES-AND-RELATED-

PRODUCTS_LABELLING_REGULATONS-2004-1.pdf

Springfield EP, Eagles PKF, Scott G. Quality assessment of South African herbal medicines by means of HPLC fingerprinting. J Ethnopharmacol. 2005; 101 (1-3): 75-83.

National Agency for Food and Drug Administration and Control

(NAFDAC), Herbal 2005. http://www.nafdac.gov.ng/guidelines/herbal-guidelines (Accessed 15 August 2014).

Mbah CC, Builders PF, Akuodor GC, Kunle OO. Pharmaceutical characterization of aqueous stem bark of extract of Bridelia fruginea Benth (Euphorbiaceae) Trop. J. Pharm Res. 2012; 11(4): 637-644.

United States Pharmacopoeia, 2007.

Well J. 2003. Pharmaceutical preformulation the physicochemical properties of drug substances. In: Aulton, M.E. (Ed.), The Science of Dosage Form Design, $2^{\text {nd }}$ ed. Churchill Livingstone, Toronto, p. 113-138.

British Pharmacopoeia 1993. The British Pharmacopoeia Commission, Vol. II, HMSO, UK.

Yacuzzi EA, Martín F, Vignola G, Mayochi V, Tollio D 2004. The sources of quality in the pharmaceutical industry. http://www.aotsargentina.org.ar/userfiles/THE\%20SOURCES\%20OF\%20 QUALITY\%20IN\%20THE\%20PHARMACEUTICAL\%20INDUSTRY.p df (Accessed 10 September 2014).

Holbrook MB, Corfman KP. 1985. Quality and value in the consumption experience: Phaedrus rides again. In Jacoby J, Olson JC. (Eds.). Perceived Quality: How Consumers View Stores and Merchandise. Massachusetts: DC Health and Company. p. 32-57.
Oniyangi O, Cohall DH. 2013. Phytomedicines (medicines derived from plants) for sickle cell disease. Cochrane Database Syst Rev. Jan 31; 1:CD004448. doi: 10.1002/14651858.CD004448.pub4. (Accessed 15 August 2014).

Ajibesin KK, Bala DN, Umoh UF. Ethno medicinal survey of plants used by the indigenes of Rivers State of Nigeria. Pharm Biol. 2012; 50(9):1123-1143. doi: 0.3109/13880209.2012.661740. (Accessed 25 August 2014)

Odugbemi, T. 2006. (Ed.) Outlines and pictures of medicinal plants from Nigeria. p.1-85.

Olowokudejo JD, Kadiri AB, Travih VA. An ethnobotanical survey of herbal markets and medicinal plants in Lagos state of Nigeria. Ethnobotl leaflets 2008; 12: 851-865.

Stability testing guidelines for dietary supplements final draft. January 2011. NSFS- stability. http://www.nsf.org/newsroom_pdf/Stability_Testing_Dietary_Supplement s.pdf

Quality control and significance of testing. http://smallb.in/sites/default/files/knowledge_base/best_practices/QualityC ontrolandsignificanceofTesting.pdf (Accessed 15 August 2014).

Kamboj A. 2012. Analytical evaluation of herbal drugs, drug discovery research in pharmacognosy. Vallisuta O. (Ed.), InTech. http://www.intechopen.com/books/drug-discovery-research-in-

pharmacognosy/analytical-evaluation-of-herbaldrugs (Accessed 25 August 2014).

Saohin W, Boonchoong P, Iamlikitkuakoon S, Jamnoiprom I. Mungdee $\mathrm{W}$. Effects of drying temperature and residual moisture content of Fa-Tha-Li (Andrographis paniculata (Burm.f.) Nees) crude powder for capsule preparation. Thai J Pharm Sci. 2007; 31: 28-35.

Saohin W, Wangmaneerat A. Songseeda S, Netsanga P. Suitable drying conditions for ginger capsule production. Isan J Pharm Sci. 2006; 2: 9-16.

Esimone CO, Chah KF, Ikejide SC. Microbiological quality of herbal preparations marketed in South East Nigeria. J. Nat. Rem. 2002; 2(1): 42-48.

National Agency for Food and Drug Administration and Control. Standard Operating Procedures (NAFDAC SOP), author Determination of moisture contents. Yaba, Lagos: Central drugs and vaccine control laboratory (CDVCL). 2000; 1-2.

Baba-Moussa F, Adjanohoun A, Anihouvi VB, Ahouandjnou H, Sanni S, Omansen TF, Kotchoni SO, Toukourou F, Baba-Moussa L. Quality-based microbial contamination analysis of nutraceuticals. Int Res J Biological Sci. 2013; 2(1): 46-51.

Nattapulwat N, Purkkao N, Suwithayapanth O. Evaluation of native and carboxymethyl yam (Dioscorea esculenta) starches as tablet disintegrants. Silpakorn U Sci \& Tech J. 2008; 2(2): 18-25.

\section{How to cite this article:}

Philip F Builders, Chris C Alalor, John A Avbunudiogba, Isreal E Justice. Survey on the Pharmaceutical Quality of Herbal Medicines Sold in Nigeria. J App Pharm Sci, 2015; 5 (06): 097-103. 